\title{
Video Pembelajaran IPS Berbasis Tri Hita Karana Untuk Kelas V Sekolah Dasar
}

I Made Dody Wahyudi ${ }^{1 *}$, Anak Agung Gede Agung ${ }^{1}$, I Wayan Sujana ${ }^{1}$

\author{
1 Universitas Pendidikan Ganesha, \\ Singaraja, Indonesia, \\ *e-mail: imadedodywahyudi19@undiksha.ac.id
}

\begin{abstract}
Abstrak
Permasalahan yang melatarbelakangi penelitian ini adalah siswa mengalami kesulitan memahami materi selama pembelajaran daring dan sulitnyanya penanaman nilai-nilai karakter kepada siswa selama pembelajaran daring. Penelitian ini bertujuan untuk mengembangkan video pembelajaran berbasis Tri Hita Karana pada muatan pembelajaran IPS siswa kelas V sekolah dasar. Muatan Tri Hita Karana diharapkan dapat menanamkan nilai-nilai karakter bakti kepada tuhan, harmoni dengan sesama, dan mengasihi lingkungan. Subjek pada penelitian ini yaitu 1 pakar konten, 1 pakar media, 1 pakar desain pembelajaran, dan 12 siswa kelas $\mathrm{V}$ SD. Jenis penelitian yang dilakukan adalah penelitian pengembangan dengan menggunakan model pengembangan yaitu model ADDIE (Analysis, Design, Development, Implementation, and Evaluations). Metode pengumpulan data yang digunakan yaitu kuesioner, observasi, wawancara. Data yang telah dikumpulkan dianalisis dengan analisis statistik deskriptif kuanittatif. Berdasarkan analisis data diperoleh validitas aspek isi 92,50\%, validitas video pada aspek desain $97,50 \%$, validitas video pada aspek media $95 \%$ dan kelayakan video pada uji coba perorangan $94,30 \%$. Video pembelajaran video pembelajaran berbasis Tri Hita Karana dinilai sangat valid dan layak digunakan pada muatan IPS kelas V SD. Media video ini memiliki kekhasan dengan memvisualisasikan nilai-nilai Tri Hita karana sehingga tertanam nilai-nilai karakter pada siswa.
\end{abstract}

Kata kunci: video, tri hita karana, IPS, ADDIE

\begin{abstract}
The problem behind this research is that students have difficulty understanding the material during online learning and the difficulty of inculcating character values in students during online learning. This study aims to develop Tri Hita Karana-based learning videos on the social studies learning content of fifth-grade elementary school students. The content of Tri Hita Karana is expected to instill the values of the character of devotion to God, harmony with others, and loving the environment. The subjects in this study were 1 content expert, 1 media expert, 1 learning design expert, and 12 grade $V S D$ students. This type of research is development research using a development model, namely the ADDIE model (Analysis, Design, Development, Implementation, and Evaluations). Data collection methods used are questionnaires, observation, interviews. The data that had been collected were analyzed using quantitative descriptive statistical analysis. Based on the data analysis, the validity of the content aspect was $92.50 \%$, the validity of the video on the design aspect was $97.50 \%$, the validity of the video on the media aspect was $95 \%$ and the feasibility of the video in the individual trial was $94.30 \%$. Tri Hita Karana-based learning video learning videos are considered very valid and suitable for use in the social studies content of class V SD. This video media has a peculiarity by visualizing the values of the Tri Hita Karana so that the character values are embedded in students.
\end{abstract}

Keywords: video learning, tri hita karana, social studies, ADDIE

\section{Pendahuluan}

IImu pengetahuan sosial atau lebih sering dikenal dengan IPS merupakan salah satu mata pelajaran yang didapatkan di sekolah dasar. IPS merupakan ilmu yang berkaitan dengan lingkungan sosial manusia. Wahida (2019) menyatakan IPS ialah bidang studi dengan pokok bahasan tentang kehidupan bermasyarakat yang terdiri dari 
kajian seperti, ekonomi, geografi, sosiologi, sejarah, antropolgi, ilmu politik dan sebagainya yang memperlihatkan masalah atau gejala sosial yang timbul di masyarakat. Secara mendasar pembelajaran IPS berkaitan dengan aspek kehidupan manusia dan bagaimana usaha manusia untuk memenuhi kebutuhan hidupnya agar dapat memepertahankan kehidupan di masyarakat (Holilah, 2016). Sesuai dengan tingkat perkembangannya, siswa pada tingkat sekolah dasar belum dapat memahami kedalaman maupun keluasan permasalahan sosial secara utuh, namun mereka bisa diperkenalkan kepada permasalahan tersebut. Melalui pembelajaran IPS siswa mampu memperoleh pengetahuan, keterampilan, sikap, dan kepekaan dalam menghadapi hidup dengan tantangannya. Selanjutnya diharapkan mereka kelak dapat bertindak secara rasional dalam memecahkan masalah-masalah yang dihadapi (Permana, 2018; Suharwati \& Rahman, 2018).

Di tingkat sekolah dasar pada kurikulum 2013 IPS merupakan salah satu muatan yang didapatkan dalam pembelajaran tematik integratif terpadu. Dimana IPS dikaitkan dengan muatan pelajaran lainnya kemudia diintegrasikan dalam tema pembelajaran. Pada masa ini, karena dunia sedang di landa wabah virus corona (Covid-19) pembelajaran di sekolah dilaksanakan secara daring (dalam jaringan). Pembelajaran daring merupakan pemanfaatan jaringan internet dalam pelaksanaan pembelajaran (Yulianingsih et al., 2020). Kebijakan yang dikeluarkan oleh pemerintah terkait dengan pelaksanaan pembelajaran daring tentunya tidak dapat berjalan dengan baik. Hal ini tentunya akan menimbulkan suatu permasalahan yang dapat menghambat pembelajaran daring. Apalagi tidak semua pelajaran bisa maksimal di lakukan dengan metode pembelajaran dalam jaringan. Salah satunya pembelajaran IPS yang banyak membahas ilmu-ilmu sosial dengan cakupan luas. Pembelajaran IPS yang disampaikan dengan daring lebih terkesan pembelajaran satu arah. Waktu yang singkat juga terkadang dimanfaatkan oleh beberapa pendidik untuk memberi tugas yang cukup memakan waktu untuk proses pengerjaannya. Kondisi ini mengakibatkan krisis referensi atau literatur oleh peserta didik. Peserta didik sulit memahami materi yang diberikan guru karena siswa hanya memiliki buku pelajaran tercetak. Walaupun dalam pelaksanaan pembelajaran IPS secara daring dapat dimanfaatkan dengan menggunaan Platform online seperti Zoom, Google meet, Google Classroom. Namun, pada prakteknya, guru lebih banyak memberikan tugas kepada siswa tanpa didukung dengan pemaparan materi, refklesi, maupun sumber belajar yang memadai (Akviansah, 2020; Qurrotaini et al., 2020). Hal senada dengan hasil wawancara yang dilakukan dengan wali kelas V di SDN 4 Penatih bahwa dalam pembelajaran daring guru hanya berpatokan pada buku siswa dan jarang menggunakan media dalam penyampaian pembelajaran disebabkan karena keterbatasan media digital yang ada, dan kurangnya kemampuan guru dalam menggunakan IT. Dampak nyata yang dirasakan siswa adalah siswa sulit memahami materi hanya mengandalkan buku teks, siswa tidak termotivasi, siswa sulit mengingat materi karena tidak memperoleh penjelasan verbal yang bisa diulang-ulang. Kesulitan-kesulitan ini telah berdampak serius terhadap tidak optimalnya hasil belajar siswa.

Berdasarkan jabaran tersebut dapat dikatakan bahwa pembelajaran IPS saat daring hanya dilakukan dengan memberikan tugas kepada siswa tanpa adanya penambahan refrensi. Jika hal ini terus dibiarkan maka akan berdampak terhadap motivasi dan minat belajar siswa. Maka dari itu perlu digunakannya media pembelajaran sebagai salah satu tamabahan refrensi yang dapat digunakan siswa dalam pelaksanaan pembelajaran daring. Salah satu media yang dapat dikembangkan yaitu media video.

Video merupakan media audio-visual yang memaparkan objek yang bergerak bersama-sama yang dapat memberikan informasi, menjelaskan proses, memaparkan konsep-konsep rumit, mengajarkan keterampilam dan memengaruhi sikap (Alamsyah et al., 2018). Video pembelajaran ialah salah satu jenis media yang mengutamakan kekuatan suara dan gambar, menyajikan audio dan visual yang berisi pesan-pesan pembelajaran baik itu konsep, prinsip, prosedur, dan teori (Farista \& Ilham, 2019; Pamungkas et al., 2018). Kelebihan dari media video pembelajaran diantaranya bersifat menyenangkan bagi siswa, mampu memberikan sajikan informasi yang konkret, dan 
mampu menghadirkan pengalaman belajar yang tidak mungkin didapatkan siswa di luar lingkungan sekolah, seperti sejarah kemerdekaan misalnya. Selain itu, video dinilai efektif untuk meningkatkan kemampuan siswa dalam memahami konsep, meningkatkan motivasi belajar siswa serta mampu meningkatkan hasil belajar siswa (Hadi, 2017; A. Riyanto, 2020).

Video pembelajaran yang dikembangkan nantinya akan menyajikan implementasi nilai-nilai Tri Hita Karana (THK). THK menjadi unsur inovatif yang disajikan dalam video. Muatan THK pada video bertujuan untuk membekali peserta didik dengan nilai-nilai karakter. Karena pada era globalisasi seperti saat ini, banyak terjadi penyimpanganpenyimpangan tingkah laku manusia dalam kehidupan sehari-hari misalnya banyak manusia yang merusak alam tanpa memikirkan akibat kedepannya (Paramandhita, 2017). Tentunya hal ini sudah mengabaikan konsep dari THK itu sendiri. Hal itu disebabkan karena terjadinya perkembangan globalisasai salah satunya akibat krisis moral yang disebakan karena kurangnya penekanan nilai-nilai budaya pada pelaksanaan pembelajaran. Selain itu, kemajuan IPTEK dan pengaruh nilai sosial budaya dari negara barat sangat berpengaruh pada pola pikir dan prilaku sebagian masyarakat terutama generasi muda, sehingga diperlukan suatu pembelajaran yang tetap memunculkan nilai lokal THK (Anjarsari,dkk, 2017). Secara konseptual THK merupakan suatu hubungan atau kehidupan yang harmonis dan seimbang antara bhakti/percaya kepada Tuhan Yang Maha Esa, mengabdikan diri kepada sesama Manusia (sosial) dan menyayangi alam lingkungan berdasarkan konsep yadnya. Sehingga dengan diselipkannya konsep Tri Hita Karana pada pengembangan video ini diharapakan nantinya siswa dapat mengambil dampak yang terjadi dalam kehidupan sehari-hari berkaitan dengan Tri Hita Karana (Yunita \& Tristiantari, 2019). Hasil-hasil penelitian menunjukkan bahwa media video yang bermutan nilai-nilai karakter mampu menjadi daya tarik bagi siswa, siswa memahami nilainilai karakter, siswa memiliki nilai yang lebih baik (Fadhli, 2016; Melinda et al., 2018; Wisada et al., 2019). Muatan THK pada video yang dikembangkan menjadi suatu hal yang baru dan perlu diketahui kelayakannya pada sebuah media video pembelajaran. Dengan demikian, pengembangan video pembelajaran berbasis Tri Hita Karana merupakan langkah strategis untuk memfasilitasi siswa belajar dan penanaman nilai-nilai karakter. Adapun tujuan dari penelitian ini yaitu untuk mengembangkan video pembelajaran IPS berbasis Tri Hita Karana yang valid dan layak diterapkan di sekolah dasar.

\section{Metode}

Penelitian ini adalah penelitian pengembangan menggunakan model ADDIE (Analysis, Design, Development, Implementation, and Evaluations) sebagai acuan langkah membuat video. Model ADDIE dipilih dikarenakan memiliki keunggulan prosedur kerjanya yang sistematis yakni pada setiap langkah yang akan dilalui selalu mengacu pada langkah sebelumnya sehingga diperoleh produk akhir yang efektif. Subjek dalam penelitian ini yaitu 1 orang ahli isi, 1 orang ahli media, 1 orang ahli desain pembelajaran, dan 12 orang siswa SD.

Pengembangan video pembelajaran berbasis Tri Hita Karana ini dilakukan dengan tahap-tahap sebagai berikut. 1) Tahap analisis yaitu melakukan analisis kebutuhan siswa, pada pembelajaran saat ini (pembelajaran jarak jauh) sehingga diperlukan media pembelajaran yang mudah dipahami dan menarik bagi siswa. 2) Tahap Desain meliputi merumuskan tujuan pembelajaran dan materi yang akan di berikan kepada siswa, serta perancangan pengembangan video pembelajaran yang di sesuaikan dengan kebutuhan belajar siswa. 3) Tahap Pengembangan meliputi merancang video pembelajaran dengan menggunakan aplikasi Adobe Premiere Pro, validasi perangkat pembelajaran oleh ahli, dan menganalisis validitas perangkat pembelajaran. 4) Tahap Implementasi yaitu mengetahui seberapa efektif pengembangan video pembelajaran terhadap mata pelajaran IPS. 5) Tahap Evaluasi yaitu pada tahap ini evaluasi yang digunakan berupa evaluasi formatif digunakan untuk mengukur atau menilai produk pembelajaran meliputi 
validasi ahli dan uji perorangan. Instrumen yang digunakan dalam penelitian ini adalah kuesioner.

Metode analisis data yang digunakan dalam penelitian pengembangan ini yaitu metode analisis deskriptif kuantitatif. Metode analisis statistik deskriptif kuantitatif merupakan suatu cara pengolahan data dengan menyusun secara sistematis berupa angka atau persentase, mengenai obejek yang diteliti, sehingga mendapatkan suatu kesimpulan umum (Anak Agung Gede Agung, 2017). Data yang dihasilkan pada penelitian ini yaitu berupa skor, saran, masukan/komentar dari sebaran kuiosioner yang diberikan. Metode analisis ini digunakan untuk mengolah data hasil riview para ahli uji coba perorangan. Hasil data yang diolah pada metode ini adalah skor hasil penyebaran kuisoner yang kemudian dihitung persentase dari masing-masing subjek untuk mengetahui hasil validitas dari produk yang dikembangkan dan selanjutnya untuk dapat memberikan pengambilan keputusan digunakan ketetapan dengan menggunakan konversi tingkat pencapaian skala 4 (skala likert) pada Tabel 2.

Tabel 2. Kriteria Kelayakan Video Pembelajaran

\begin{tabular}{ccccc}
\hline No & Persentase Penguasaan & $\begin{array}{c}\text { Nilai } \\
\text { Angka }\end{array}$ & Nilai huruf & Predikat \\
\hline 1 & $90-100$ & 4 & A & Sangat Baik \\
2 & $80-89$ & 3 & B & Baik \\
3 & $65-79$ & 2 & C & Cukup \\
4 & $55-64$ & 1 & D & Kurang \\
5 & $0-54$ & 0 & E & Sangat Kurang \\
\hline & & & & (Sumber: Agung, 2010)
\end{tabular}

\section{Hasil dan Pembahasan}

Deskripsi data yang dibahas pada penelitian pengembangan ini terdiri dari deskripsi rancangan media video pembelajaran berbasis Tri Hita Karana dan deskripsi validitas media video pembelajaran berbasis Tri Hita Karana. Rancangan media video pembelajaran berbasis Tri Hita Karana menggunakan tahapan-tahapan dari model ADDIE, yang terdiri dari lima tahapan yaitu analisis, desain, pengembangan, implementasi, dan evaluasi.

Tahap pertama, yaitu tahap analisis. Tahap analisis ialah suatu proses memperoleh informasi yang nantinya akan dijadikan sebagai pedoman dalam memecahkan permasalahan yang ada dilapangan. Pada tahap ini analisis yang dimaksud terdiri dari analisis karakteristik siswa, analisis konten dan analisis lingkungan sekolah, yang diperoleh dengan cara angket/kuisioner, wawancara, dan observasi. Kegiatan penyebaran angket/kuisioner dilakukan untuk mengetahui mengenai karakteristik siswa tentang kapasitas belajaranya, kompetensi pengetahuannya, keterampilan dan sikap yang dimiliki oleh siswa di SD Negeri 4 Penatih, yangmana hasil dari kegiatan ini digunakan untuk menganalisis kebutuhan siswa terutama berupa materi dan sumber pembelajaran yang relevan, serta menganalisis media pembelajaran yang akan diterapkan. Kegiatan wawancara digunakan untuk menganalisis konten atau pemilihan materi pembelajaran yang tepat dengan menyesesuaikan produk yang nantinya akan dikembangkan disertai analisis karakteristik dan kemampuan yang dimiliki masing-masing siswa. Berdasarkan wawancara dengan guru kelas V SD Negeri 4 Penatih materi yang akan dicantumkan dalam video pembelajaran berbasis Tri Hita Karana yaitu mengenai interaksi manusia dengan lingkungan dan pengaruhnya terhadap pembangunan social budaya dan ekonomi pada mata pelajaran IPS. Sedangkan kegiatan observasi digunakan untuk mengetahui keadaan lingkungan dan fasilitas yang ada di SD Negeri 4 Penatih agar nantinya dapat menunjang pelaksanaan penelitian.

Tahap kedua, yaitu tahap desain. Pada tahap ini kegiatan yang dilakukan adalah membuat rancangan produk sebelum di kembangkan, yang terdiri dari 1) kegiatan membuat desain (storyboard) terkait materi yang akan dikembangkan, 2) mendesain 
komponen media dengan menggunakan softweare Adobe Premiere Pro2019, 3) menyusun instrumen penilaian.

Tahap ketiga, yaitu tahap pengembangan. Pada tahap ini video pembelajaran yang sudah di rancang di kembangkan sesuai dengan rancangan yang sudah dibuat sebelumnya serta materi yang sesuai dengan yang sudah di siapkan. Pada tahap ini video di kembangkan dan di rancang dengan menggunakan bantuan aplikasi Adobe Premiere Pro 2019.

Tahap keempat, yaitu tahap implementasi. Pada tahap implementasi ini kegiatan yang dilakukan adalah melakukan uji validtas produk yang terdiri dari 1) uji validitas produk oleh para ahli diantaranya yaitu ahli isi mata pelajaran, ahli media pembelajaran, dan ahli desain pembelajaran. 2) Uji coba produk, yang meliputi uji perorangan yang terdiri dari tiga siswa, Kegiatan uji validitas ini bertujuan untuk mengukur kelayakan produk yang dikembangkan.

Tahap kelima, yaitu tahap evaluasi. Tahap evaluasi merupakan tahapan terakhir yang dilakukan. Pada tahap ini dilakukan evaluasi menggunakan evaluasi formatif. Evaluasi formatif dilakukan untuk menilai produk video pembelajaran yang di kembangkan. Evaluasi formatif mencakup validasi para ahli dan uji coba perorangan.

Uji coba produk dilakakukan untuk mengetahui kelayakan produk yang dikembangkan, uji coba produk yang dilakukan terdiri dari uji ahli isi mata pelajaran, uji ahli desain pembelajaran, uji ahli media pembelajaan, dan uji coba perorangan yang dinilai oleh tiga orang siswa yang memiliki kemampuan yang berbeda di SD Negeri 4 Penatih. Instrument yang digunakan untuk mengetahui validitas produk yang dikembangkan yaitu menggunakan kuisioner. Hasil analisis data pada tahap pengembangan video pembelajaran yang terdiri dari uji ahli isi mata pelajaran, uji ahli media pembelajaran, uji ahli desain pembelajaran, dan uji coba perorangan disajikan pada Tabel 6.

Tabel 6. Presentase Hasil Validitas Pengembangan Video Pembelajaran

\begin{tabular}{cccc}
\hline No & Subjek Uji Coba & Hasil Validitas (\%) & Kualifikasi Presentase \\
\hline 1. & Uji Ahli Isi Mata Pelajaran & 92,50 & Sangat Baik \\
2. & Uji Ahli Desain Pembelajaran & 97,50 & Sangat Baik \\
3. & Uji Ahli Media Pembelajaran & 95 & Sangat Baik \\
4. & Uji Coba Perorangan & 94,30 & Sangat Baik \\
\hline
\end{tabular}

Berdasarkan Tabel 6 menunjukkan bahwa hasil validitas pengembangan media pembelajaran video berbasis THK menurut ahli isi materi memperoleh presentase sebesar $92,50 \%$ dengan kualifikasi sangat baik, hasil validitas menurut ahli desain pembelajaran memperoleh presentasi sebesar $97,50 \%$ dengan kualifikasi sangat baik, hasil validitas menurut ahli media pembelajaran memperoleh presentase sebesar $95 \%$ dengan kualifikasi sangat baik, dan hasil validitas uji coba perorangan memperoleh presentase sebesar 9,30\% dengan kualifikasi sangat baik. Dari hasil uji validitas keseluruhan yang telah dilakukan dapat disimpulkan bahwa media video pembelajaran berbasis Tri Hita Karana yang dikembangkan sangat layak untuk digunakan walaupun terdapat sedikit saran atau masukan yang diberikan oleh para ahli dari uji validitas yang dilakukan guna menyempurnakan media pembelajaran yang dikembangkan. Saran atau masukan yang diberikan baik dari uji ahli isi mata pelajaran, uji ahli desain pembelajaran, uji ahli media pembelajaan, dan uji coba perorangan disajikan pada Tabel 7 sedangkan untuk hasil pengembangan produk video pembelajaran berbasis Tri Hita Karana disajikan pada gambar 1. 
Tabel 7. Perbaikan Produk Pengembangan Uji Ahli Isi Mata Pelajaran, Uji Ahli Desain Pembelajaran, Uji Ahli Media Pembelajaan, Dan Uji Coba Perorangan

\begin{tabular}{|c|c|c|c|}
\hline No & Subjek & Komentar dan Saran & Revisi \\
\hline 1. & $\begin{array}{l}\text { Ahli Isi Mata } \\
\text { Pelajaran }\end{array}$ & $\begin{array}{l}\text { Materi perlu ditambahkan } \\
\text { konsep, fakta, prinsip/prosedur. }\end{array}$ & $\begin{array}{l}\text { Menambahkan materi } \\
\text { mengenai konsep, fakta, } \\
\text { prinsip/prosedur. }\end{array}$ \\
\hline 2 & $\begin{array}{l}\text { Ahli Desain } \\
\text { Pembelajaran }\end{array}$ & $\begin{array}{l}\text {-Presenter agar tidak terus } \\
\text { menerus kelihatan di depan } \\
\text { layar. } \\
\text {-Perlu adanya profil pengembang } \\
\text { di awal video dan ucapan terima } \\
\text { kasih di akhir video }\end{array}$ & $\begin{array}{l}\text {-Merevisi agar presenter } \\
\text { tidak terus menerus } \\
\text { kelihatan di depan layar. } \\
\text {-Menambahkan profil } \\
\text { pengembang di awal video } \\
\text { dan ucapan terima kasih } \\
\text { di akhir vdeo }\end{array}$ \\
\hline 3 & $\begin{array}{l}\text { Ahli Media } \\
\text { Pembelajaran }\end{array}$ & $\begin{array}{l}\text {-Perlu adanya panduan dalam } \\
\text { pengguanan video pembelajaran } \\
\text {-Pembuatan cover CD }\end{array}$ & $\begin{array}{l}\text {-Membuat panduan video } \\
\text { pembelajaran } \\
\text {-Pembuatan cover CD }\end{array}$ \\
\hline 4 & $\begin{array}{l}\text { Tiga siswa SDN } 4 \\
\text { Penatih (Uji coba } \\
\text { perorangan) }\end{array}$ & $\begin{array}{l}\text { Video pembelajarn sangat bagus } \\
\text { dan menarik. }\end{array}$ & 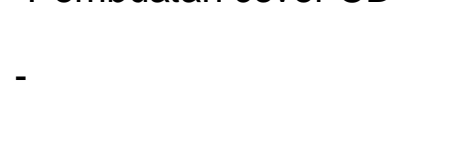 \\
\hline
\end{tabular}

Adapun gambar revisi dari hasil produk video pembelajaran berbasis tri hita karana seperti berikut ini.
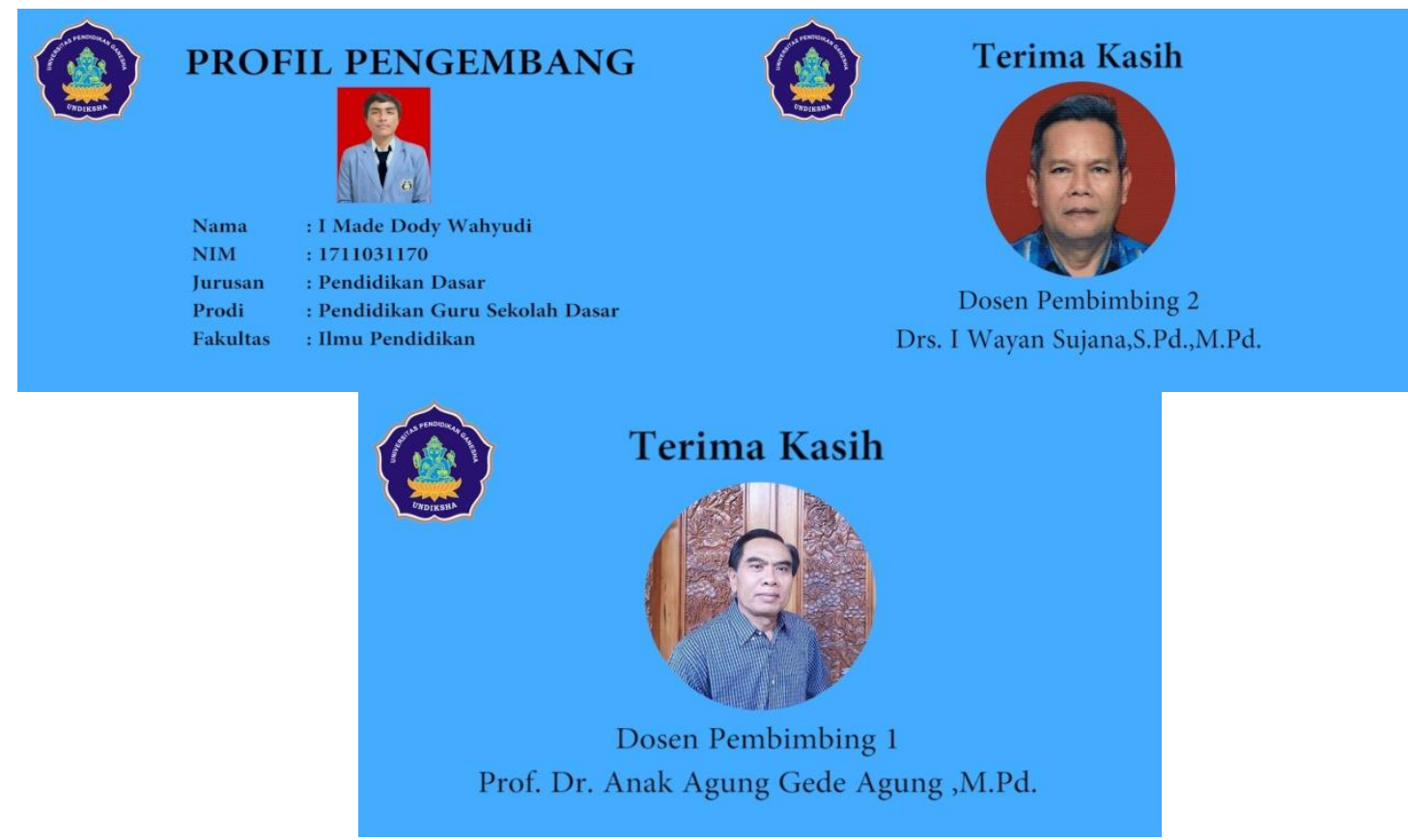

Gambar 1. Sesudah Revisi Penambahan Profil Pengembangan dan Ucapan Terima Kasih di Akhir Video 


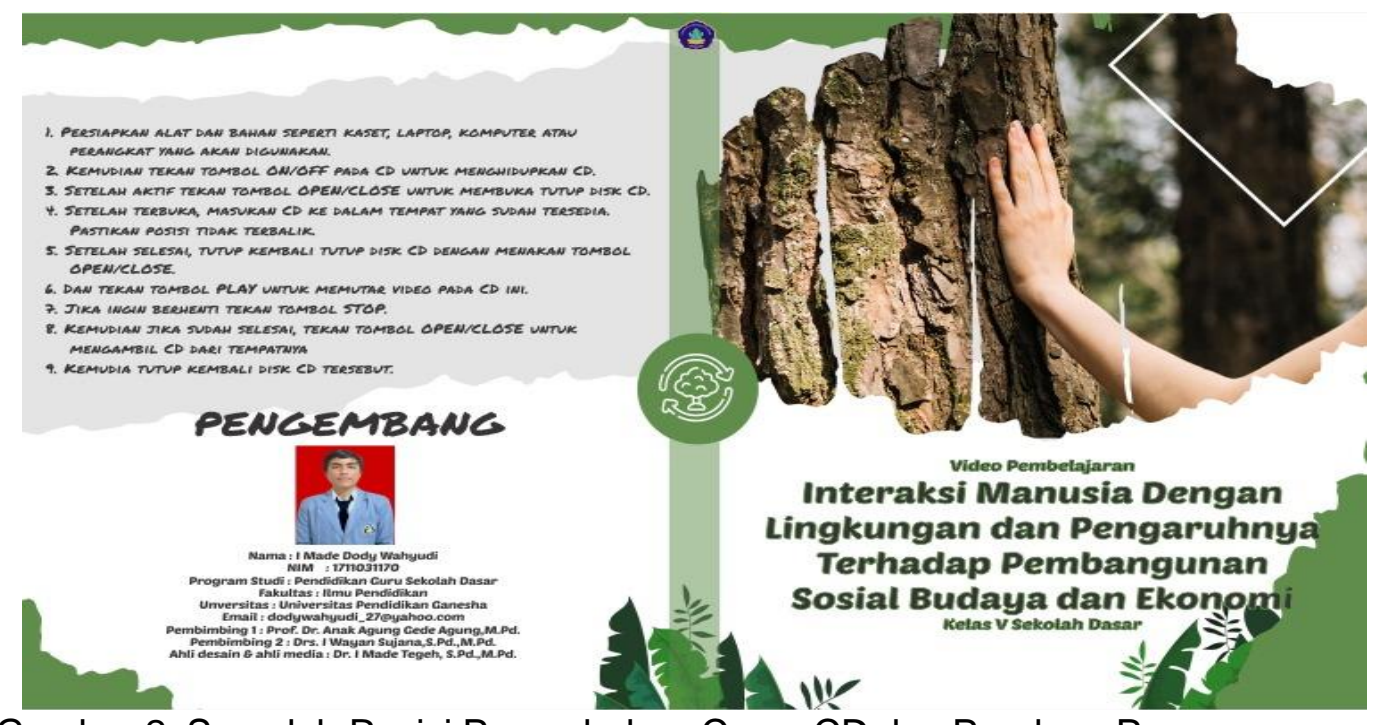

Gambar 2. Sesudah Revisi Penambahan Cover CD dan Panduan Penggunaannya

Berdasarkan deskripsi validitas pengembangan video pembelarajan, hasil validitas pengembangan video pembelajaran secara keseluruhan memperoleh persentase sangat baik. Validitas video pembelajaran dari aspek isi memperoleh persentase sebesar $92,50 \%$ dengan kategori sangat baik. Hal ini tidak terlepas dari pengembangan video dengan memperhatikan aspek kurikulum, relevansi isi, kemudahan bahasa, ketepatan visualisasi nilai-nilai THK. Video pembelajaran telah mengacu pada kurikulum yang berlaku yaitu kurikulum 2013. Dari kurikulum ini diturunkan tujuan pembelajaran yang akhirnya kembali ke pencapaian tujuan karena media video sebagai alat perantara agar tercapai tujuan secara efektif dan efisien (Tafonao, 2018). Rumusan tujuan menjadi acuan untuk mengembangkan isi pada video pembelajaran. Pada aspek bahasa dipilih kosata yang familiar dengan anak SD. Pemilihan kata dan susunan kalimat dalam video dibuat sederhana, mudah dimengerti, dan terkesan lebih akrab atau memperhatikan prinsip personalisasi. Penerapan prinsip ini pada bahan ajar termasuk video dapat memberikan efek lebih baik kepada siswa (Rey \& Steib, 2013)

Pada aspek desain pembelajaran diperoleh persentase $97,50 \%$ dengan kategori sangat baik. Video pembelajaran telah dikembangkan dengan memperhatikan rumusan tujuan yang lengkap, petunjuk belajar, strategi penyajian pesan, dan aspek evaluasi. Rumusan tujuan menjadi acuan utama untuk menentukan urutan penyajian pesan, petunjuk belajar, strategi dan aspek evaluasi. Tujuan pembelajaran pada video disajikan pada bagian awal sehingga memberikan acuan utama kepada pendidik dan siswa tentang apa yang mesti dicapai. Petunjuk belajar juga disajikan pada bagian awal sebagai pedoman agar siswa bisa berhasil belajar selama menyimak materi pada video. Deskripsi atau petunjuk penggunaan dapat memberikan kemudahan kepada guru maupun siswa dalam mengoperasikan media pembelajaran (Rozie, 2018). Strategi penyajian pesan video mengadopsi teori segementasi yang artinya bahwa materi dipecah menjadi segmen-segmen kecil. Setiap segmen ditayangkan secara urut dan sistematis. Penerapan prinsip ini dapat memudahkan siswa mengorganisasikan dan mengintegrasikan pengetahuan yang kompleks sekaligus meningkatkan hasil belajar mereka (Ibrahim et al., 2012; W. D. Riyanto \& Gunarhadi, 2017).

Validitas video pada aspek media memperoleh persentase $95 \%$ dengan kategori sangat baik. Perolehan kualifikasi sangat baik ini dikarenakan video yang dikembangkan sesuai dengan karakteristik peserta didik. Dimana dalam pembuatan media pembelajaran tentunya harus sesuai dengan karakteristik siswa agar siswa tertarik dan dapat fokus serta memahami materi yang akan disampaikan dengan baik. Hal ini, sejalan dengan pendapat Nurdewanto et al., (2018) yang menyatakan bahwa video pembelajaran adalah video pembelajaran sebagai media yang digunakan untuk merangsang pikiran, perasaan, 
dan kemauan siswa untuk belajar melalui penayangan ide atau gagasan, pesan dan informasi secara audio visual. Tampilan video pembelajaran, produk video pembelajaran sudah menggunakan gambar-gambar yang dipadukan dengan teks untuk mendukung pesan yang terkandung dalam video sehingga video pembelajaran menjadi menarik dan mudah di pahami. Gambar bergerak maupun diam merupakan unsur penting dalam video pembelajaran dan sangat membantu pembelajar memahami pesan yang ingin di sampaikan (Sudarma et al., 2015). Secara ilmu psikologis penggunaan gambar yang menarik sangat membantu perkembangan psikologis anak sehingga berdampak pada minat dan motivasi siswa untuk belajar (Supriyono, 2018).

Kelayakan video pada tahap uji coba perorangan memperoleh persentase $94,30 \%$ dengan kategori sangat baik. Perolehan kualifikasi sangat baik ini terihat dari komentar yang di berikan oleh siswa bahwa video pembelajaran mendapatkan respon yang positif dari siswa, karena video mampu menarik perhatian dan menumbuhkan motivasi dalam belajar. Media video yang efektif adalah media yang mampu: (1) media pembelajaran dapat meningkatkan perhatian siswa dan memunculkan motivasi dalam belajar, (2) media pembelajaran kiranya memberi arah yang jelas tentang penyampaian pesan dan informasi untuk kelancaran pembelajaran, (3) media pembelajaran khendaknya menyamakan pemahaman dan pengalaman peserta didik tentang materi yang dipelajari sehingga interaksi dapat berlangsung, dan (4) media pembelajaran dapat memberi solusi keterbatasan indera, waktu dan ruang, (5) menyajikan tayangan yang jelas dan konkret (Awalia et al., 2019; Azhar, 2011). Aspek lain yang menjadi keunggulan video yang dikembangkan yaitu mampu menarik perhatian walau dengan durasi singkat, menyajikan visualisasi THK sebagai pelengkap materi yang memberikan wawasan lebih di luar mata pelajaran IPS, dan memiliki tugas-tugas yang dapat diimplementasikan di lingkungan rumah atau masyarakat. Hal unik seperti visualisasi THK pada video akan dapat melengkapi pengalaman-pengalaman dasar siswa (Busyaeri et al., 2016; Chandra \& Nugroho, 2016). Visulisasi konten pelajaran maupun THK dapat melatih siswa untuk berpikir logis, analisistik, kreatif, dan dapat merangsang pengetahuan siswa, serta dapat melatih imajinasi sehingga pembelajaran menjadi efektif dan menyenangkan (Hardianti \& Asri, 2017). Maka dari itu, pengembangan video pembelajaran berbasis THK dianggap layak digunakan sebagai solusi meningkatkan perhatian, meningkatkan hasil belajar termasuk penanaman nilai-nilai kearifan lokal Bali selama pembelajaran daring di masa covid-19.

\section{Simpulan}

Review yang dilakukan oleh ahli isi mata pelajaran, ahli desain pembelajaran, ahli media pembelajaran dan hasil uji coba perorangan media video pembelajaran berbasis Tri Hita Karana berada pada kategori sangat baik. Dapat disimpulkan bahwa media video pembelajaran berbasis Tri Hita Karana telah memenuhi kriteria valid dan layak digunakan oleh peserta didik khusus dalam mempelajari materi IPS. Media ini juga layak digunakan untuk menanamkan nilai-nilai karakter berbasis kearifan lokal Bali yaitu bakti kepada Tuhan, harmoni dengan sesasam, dan asih kepada lingkungan.

\section{Daftar Pustaka}

Agung, A.A.G. (2010). Pengantar Evaluasi Pendidikan. Universitas Pendidikan Ganesha.

Agung, Anak Agung Gede. (2017). Buku Ajar Evaluasi Pendidikan. Universitas Pendidikan Ganesha.

Akviansah, M. D. (2020). Perpustakaan Maya sebagai Sumber Belajar dan Penunjang Pembelajaran IPS secara Daring di Era Pandemi COVID-19. Jurnal Teori Dan Praksis Pembelajaran IPS, 92-102. https://core.ac.uk/download/pdf/354310742.pdf

Alamsyah, R., Toenlioe, A. J. E., \& Husna, A. (2018). Pengembangan Video Pembelajaran Kepenyiaran Materi Produksi Program Televisi Untuk Mahasiswa 
Teknologi Pendidikan Universitas Malang. Jurnal Kajian Teknologi Pendidikan, 1(3), 229-236. http://journal2.um.ac.id/index.php/jktp/article/view/4563

Anjarsari, K. Y., Suniasih, N. W., \& Sujana, I. W. (2017). Pengaruh Model Pembelajaran Talking Chips Berbasis Tri Hita Karana Terhadap Kompetensi Pengetahuan IPS. Mimbar PGSD, 5(2). https://doi.org/http://dx.doi.org/10.23887/jjpgsd.v5i2.10659

Awalia, I., Pamungkas, A. S., \& Alamsyah, T. P. (2019). Pengembangan Media Pembelajaran Animasi Powtoon pada Mata Pelajaran Matematika di Kelas IV SD. Kreano, Jurnal Matematika Kreatif-Inovatif, 10(1), 49-56. https://doi.org/10.15294/kreano.v10i1.18534

Azhar, A. (2011). Media Pembelajaran. Raja Grafindo Persada.

Busyaeri, A., Udin, T., \& Zaenudin, A. (2016). Pengaruh Penggunaan Video Pembelajaran Terhadap Peningkatan Hasil Belajar Mapel IPA di Min Kroya Cirebon. Al Ibtida: Jurnal Pendidikan Guru MI, 3(1), 116-137. https://doi.org/10.24235/al.ibtida.snj.v3i1.584

Chandra, F. H., \& Nugroho, Y. W. (2016). Peran Teknologi dalam Flipped Classroom. Jurnal Ilmiah Teknologi Dan Rekayasa, 8(1), 15-20. http://dinatek.stts.edu/pdf/04_2016_8_1/5.Francisca_Haryanti_Chandra.pdf

Fadhli, M. (2016). Pengembangan Media Pembelajaran Berbasis Video Kelas IV Sekolah Dasar. Jurnal Dimensi Pendidikan Dan Pembelajaran, 3(1), 24-33.

Farista, R., \& Ilham, A. M. (2019). Pengembangan Video Pembelajaran. Universitas Muhammadiyah Sidoarjo, 53(9), 1689-1699.

Hadi, S. (2017). Efektivitas Penggunaan Video Sebagai Media Pembelajaran Untuk Siswa Sekolah Dasar. Prosiding TEP \& PDs, Tema: 1 No, 96-102.

Hardianti, H., \& Asri, W. K. (2017). Keefektifan Penggunaan Media Video Dalam Keterampilan Menulis Karangan Sederhana Bahasa Jerman Siswa Kelas XII IPA SMA Negeri 11 Makassar. Eralingua: Jurnal Pendidikan Bahasa Asing Dan Sastra, 1(2), 123-130. https://doi.org/10.26858/eralingua.v1i2.4408

Holilah, M. (2016). Kearifan Ekologis Budaya Lokal Masyarakat Adat Cigugur Sebagai Sumber Belajar Ips. Jurnal Pendidikan IImu Sosial, 24(2), 163. https://doi.org/10.17509/jpis.v24i2.1453

Ibrahim, M., Antonenko, P. D., Greenwood, C. M., \& Wheeler, D. (2012). Effects of segmenting, signalling, and weeding on learning from educational video. Learning, Media and Technology, 37(3), 220-235. https://doi.org/10.1080/17439884.2011.585993

Melinda, V. A., Degeng, I. N. S., \& Kuswandi, D. (2018). Pengembangan Media Video Pembelajaran IPS Berbasis Virtual Field Trip (VFT) Pada Kelas V SDNU KratonKencong. Jinotep (Jurnal Inovasi Dan Teknologi Pembelajaran) Kajian Dan Riset Dalam Teknologi Pembelajaran, 3(2), 158-164. https://doi.org/http://dx.doi.org/10.17977/um031v3i22017p158

Nurdewanto, B., Sonalitha, E., Rusdijanto, \& Sunarwan, A. (2018). Multimedia Learning Untuk Sekolah Dasar. Jurnal Pengabdian Masyarakat Universitas Merdeka Malang, 3(2), 14-18. https://doi.org/10.26905/abdimas.v3i2.2587

Pamungkas, A. S., Ihsanudin, I., Novaliyosi, N., \& Yandari, I. A. V. (2018). Video Pembelajaran Berbasis Sparkol Videoscribe: Inovasi Pada Perkuliahan Sejarah

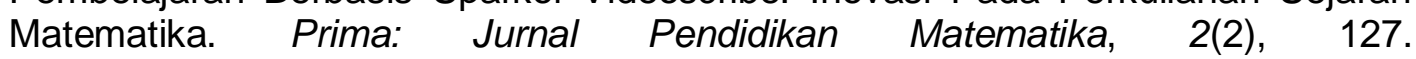
https://doi.org/10.31000/prima.v2i2.705

Paramandhita, A. (2017). Penerapan Ajaran Tri Hita Karana Pada Anak Usia Dini di TK 
Dharmayasa Kecamatan Klungkung Kabupaten Klungkung. Jurnal Penelitian Agama Hindu, 1(2), 205-208.

Permana, E. P. (2018). Pengaruh Media Sosial sebagai Sumber Belajar IPS Terhadap Motivasi Belajar, Kemampuan Berpikir Kritis dan Berpikir Kreatif Siswa Sekolah Dasar. Jurnal Pinus, 4(1), 54-59. https://doi.org/10.29407/pn.v4i1.12431

Qurrotaini, L., Khusnussyifa, N., Sundi, V. H., \& Nurmalia, L. (2020). Analisis Faktor Hambatan Penerapan IPS di SD pada Pembelajaran Daring. Seminar Penelitian LPPM UMJ, 1(1), 90-109.

Rey, G. D., \& Steib, N. (2013). The personalization effect in multimedia learning: The influence of dialect. Computers in Human Behavior, 29(5), 2022-2028. https://doi.org/10.1016/j.chb.2013.04.003

Riyanto, A. (2020). Penggunaan Video Sebagai Media Tutorial Pembelajaran Terhadap Kemampuan Berceramah Siswa. Jurnal KIBASP (Kajian Bahasa, Sastra Dan Pengajaran), 3(2), 231-238. https://doi.org/https://doi.org/10.31539/kibasp.v3i2.1111

Riyanto, W. D., \& Gunarhadi, G. (2017). The Effectiveness of Interactive Multimedia in Mathematic Learning: Utilizing Power Points for Students with Learning Disability. IJPTE : International Journal of Pedagogy and Teacher Education, 1(1), 55-63. https://doi.org/10.20961/ijpte.v1i1.8400

Rozie, F. (2018). Persepsi Guru Sekolah Dasar Tentang Penggunaan Media Pembelajaran Sebagai Alat Bantu Pencapaian Tujuan Pembelajaran. Widyagogik, 5(2), 1-12. https://doi.org/https://doi.org/10.21107/widyagogik.v5i2.3863

Sudarma, I. K., Tegeh, I. M., \& Prabawa, D. G. A. P. (2015). Desain Pesan Kajian Analisis Desain Visual Teks dan Image. Graha Ilmu.

Suharwati, S. I., \& Rahman, A. M. (2018). Menumbuhkan Karakter Cinta Lingkungan dalam Pembelajaran IPS di Sekolah Dasar Melalui Outdoor Study. Prosiding Seminar, 53(9), 253-260.

Supriyono. (2018). Pentingnya Media Pembelajaran Untuk Meningkatkan Minat Belajar Siswa SD. Edustream: Jurnal Pendidikan Dasar, II(1), 43-48. https://journal.unesa.ac.id/index.php/jpd/article/view/6262

Tafonao, T. (2018). Peranan Media Pembelajaran Dalam Meningkatkan the Role of Instructional Media To Improving. Komunikasi Pendidikan, 2(2), 105.

Wahida, S. N., Ramly, \& Halim, M. (2019). Perbedaan Hasil Belajar IPS Menggunakan Model Problem Based Learning (PBL) Dan Model Pembelajaran Kooperatif Tipe Number Head Together (NHT) Ditinjau Dari Kreativitas Belajar Siswa Kelas VIII SMPN 2 Raha. Jurnal Wahana Kajian Pendidikan IPS, 3(1), 42-48. https://doi.org/http://dx.doi.org/10.33772/jwkp-ips.v3i1.7935

Wisada, P. D., Sudarma, I. K., \& Yuda S, A. I. W. I. (2019). Pengembangan Media Video Pembelajaran Berorientasi Pendidikan Karakter. Journal of Education Technology, 3(3), 140. https://doi.org/10.23887/jet.v3i3.21735

Yulianingsih, W., Suhanadji, S., Nugroho, R., \& Mustakim, M. (2020). Keterlibatan Orangtua dalam Pendampingan Belajar Anak selama Masa Pandemi Covid-19. Jurnal Obsesi: Jurnal Pendidikan Anak Usia Dini, 5(2), 1138-1150. https://doi.org/10.31004/obsesi.v5i2.740

Yunita, N. K. D., \& Tristiantari, N. K. D. (2019). Pengaruh Model Pembelajaran Kooperatif Tipe TGT Berbasis Kearifan Lokal Tri Hita Karana Terhadap Hasil Belajar. Jurnal $\begin{array}{llll}\text { Pendidikan Multikultural Indonesia, } & \end{array}$ https://doi.org/http://dx.doi.org/10.23887/jpmu.v1i2.20778 